
strawberry fruits. Horticultura Brasileira 26: 371-374.

\title{
Sensory analysis and chemical characterization of strawberry fruits
}

\author{
Juliano Tadeu V de Resende; Letícia KP Camargo; Eliana JS Argandoña; Aline Marchese; Cristhiano K \\ Camargo
}

UNICENTRO-Dep ${ }^{\text {to. }}$ de Agronomia, Campus Universitário CEDETEG , C. Postal 3010, 85040-080 Guarapuava-PR; jresende@ unicentro.br; lpinheiro@unicentro.br

\begin{abstract}
The aim of this work was to carry out the chemical characterization and sensory analysis of strawberry fruits from cultivars Camp-dover, Dover, Camp-oso, Oso Grande, and TudlaMilsei, grown in the southern region of Minas Gerais State. Soluble solids, titratable acidity, and the ratio between both characteristics were evaluated, in three replications. Sensory analysis was carried out by a panel of 34 non-trained assessors, recruited out of UNICENTRO students, professors, and employees. Assessors evaluated the samples for aroma and flavor using sorting-preference tests, with scores from 1 (less preferred) to 5 (most preferred). Appearance was assessed by means of a hedonic scale, from 1 (dislike very much) to 9 (like very much). Each assessor evaluated five samples of each cultivar for aroma and flavor. To evaluate external appearance, fruits were presented in polystyrene trays, covered with transparent film. Cultivars Camp-dover, Oso Grande, and TudlaMilsei had the highest $(\mathrm{p}<0.05)$ contents of soluble solids (respectively 8.1, 7.8, and $7.6^{\circ}$ Brix); while for titratable acidity, the highest values were found in fruits of cultivars Tudla-Milsei, Oso Grande, and Dover $(0.88,0.80$, and 0.60$)$. For the soluble solids:titratable acidity ratio, cultivar Camp-dover (13.5) significantly exceeded all others. Fruits from cultivars Camp-dover and Oso Grande, for their good scores in aroma (3.70 and 2.80, respectively), flavor (3.82 and 3.52), and appearance (7.00 and 7.38) had the best acceptability. Considering the results all together, cultivars Campdover and Oso Grande stood out as promising options for strawberry growing, since their advantageous fruit characteristics are likely to favor commercialization.
\end{abstract}

Keywords: Fragaria x ananassa, soluble solids, titratable acidity, acceptability, flavor.

\begin{abstract}
RESUMO
Análise sensorial e caracterização química de frutos de morango

O trabalho teve como objetivo realizar a caracterização química e a análise sensorial de morangos das cultivares Camp-dover, Dover, Camp-oso, Oso Grande e Tudla-Milsei, produzidas na região Sul de Minas Gerais. Foram avaliados teor de sólidos solúveis e acidez titulável, além da razão entre as duas características, em três repetições. A análise sensorial foi realizada por um painel de 34 avaliadores, formado por alunos, professores e funcionários da UNICENTRO. $\mathrm{O}$ painel avaliou o aroma e o sabor dos frutos utilizando testes de ordenação-preferência, com notas variando de 1 (menor preferência) a 5 (maior preferência). A aparência foi avaliada por meio de escala hedônica, de 1 (desgostei muito) a 9 (gostei muito). Cada painelista avaliou cinco amostras de cada cultivar para aroma e sabor. Para avaliação da aparência, os frutos foram apresentados em bandejas plásticas, cobertas com filme plástico transparente. As cultivares CampDover, Oso Grande e Tudla-Milsei apresentaram os teores de sólidos solúveis significativamente $(\mathrm{p}<0,05)$ mais altos (respectivamente 8,1 , 7,8 e 7,6 ${ }^{\circ}$ Brix), enquanto as cultivares Tudla-Milsei, Oso Grande e Dover apresentaram os valores significativamente mais elevados para acidez titulável $(0,88,0,80$ e 0,60$)$. A cultivar Camp-dover superou significativamente todas as demais para o valor da relação entre sólidos solúveis e acidez titulável (13,5). Os frutos das cultivares Campdover e Oso Grande, devido às boas notas em aroma (3,70 e 2,80, respectivamente), sabor (3,82 e 3,52) e aparência $(7,00$ e 7,38) apresentam a melhor aceitabilidade. Considerando todos os resultados em conjunto, as cultivares Camp-dover e Oso Grande podem ser consideradas opções de plantio promissoras, já que as boas características de seus frutos irão favorecer a comercialização.
\end{abstract}

Palavras-chave: Fragaria x ananassa, sólidos solúveis, acidez titulável, aceitabilidade, sabor.

\section{(Recebido para publicação em 15 de junho de 2007; aceito em 11 de julho de 2008)}

S trawberry production in Brazil is concentrated in the states of Minas Gerais (40\% of the total supply), São Paulo, and Rio Grande do Sul. The remaining of the production is dispersed, especially in the South region. From the total production, $50 \%$ goes to the fresh market, while the other half is used as ingredient in the food industry or as frozen fruit pulp (Veiga Junior, 2005). Strawberry production arouses interest due to its high profitability when compared to corn or soybean (Ronque, 1998). Independently of the purpose, fresh market or processing, strawberry reaches relatively high prices, since it is harvested from late autumn to midspring, when there is no competition with other fruits. Strawberry production increased in average $6.3 \%$ annually in the last decade in comparison to an annual average rate of $3.7 \%$, for other fruit and vegetables in the same period (Veiga Junior, 2005).

In commercial strawberry, pseudofruits are the edible part. Pseudofruits are juicy bright-red fleshy receptacles, with characteristic aroma and flavor, and rich in vitamins, especially ascorbic acid or vitamin $\mathrm{C}$
(Reichert \& Madail, 2003). Strawberry, owing to its flavor, aroma, color and external appearance, is a very popular fruit. It is also one of the most important fruit-producing vegetable crops, both in Brazil and in the world. Global strawberry production is increasing, in response to a mounting market demand, particularly in the largest world economies (Reichert \& Madail, 2003).

Sensory attributes (color, texture, aroma), as well as the chemical constituents (sugar:acid balance) are determinant in fruit quality. In strawberry, flavor, which is partially 
dependent on the sugar:acid balance, is the most important attribute for consumers. Fruit color, which is visually very appealing, is related to the content of antocianins, a natural pigments derived from sugar. Texture is dependent on the polysaccharide structure, which determines also flavor and aroma, and on the release of the organic compounds present in the tissues and perceptible to the taste (Chitarra \& Chitarra, 2005). Malic and citric acids are some of the organic compounds found in strawberry fruits. These acids have a direct influence over flavor, the pectin jelly properties, and fruit pigment synthesis, and act also in the control of cell $\mathrm{pH}$ (Flores-Cantillano et al., 2003).

In mature strawberry fruits, flavor corresponds to the relation between sweet and acid constituents. Considering that maturation is the outcome of a set of species-specific physical and chemical changes, flavor is cultivar dependent, although it varies also according to cropping conditions. During the maturation process, there is a significant rise in sugar content, mainly glucose, fructose, and saccharosis, which may correspond up to $99 \%$ of the total sugar content; with consequent reduction in total acidity and increase in vitamin $\mathrm{C}$ (Flores-Cantillano et al., 2003).

The sensory attributes to be considered in strawberry fruits are appearance (assessed by means of size, shape, color, brightness, and defects), flavor, aroma, texture, and nutritional value. According to Lima (1999), it is crucial that these characteristics are evaluated in close comparison to a control that represents consumer preferences, also because sensory attributes may vary as function of climatic conditions during plant development.

Currently, several foreign strawberry cultivars are in use in Brazil, which implies in differences in fruit yield and quality, according to the environmental peculiarities of each Brazilian growing region. It is worthy mentioning that the fruit physical and chemical composition, which is characteristic of each cultivar, is also altered as function of climatic diversification. Flavor, aroma, appearance, acidity, and content of soluble solids are directly related to the cultivar and to the cultivar $x$ environment interaction as well. Consequently, the knowledge of the environmental factors is substantially important in the determination of cultivar adaptation, in addition obviously to consumer preferences.

Considering that sensory aspects can be easily distinguished by consumers, sensory analysis is necessary to measure, evaluate, and interpret consumer reactions, and how sensory aspects are perceived by the human senses, namely sight, smell, taste, touch, and hearing. Sensory analysis uses the human ability to quantify and compare sensory attributes to evaluate food and drinks. To accomplish reliable results, sensory analyses are carried out using methodologies that are specific to the study purposes (Ferreira, 1999).

The objectives of the present work were to identify consumer preferences and to check the acceptability of strawberry fruits from different cultivars, by means of sensory and chemical analyses.

\section{MATERIAL AND METHODS}

Strawberry cultivars Camp-dover, Dover, Camp-oso, Oso Grande, and Tudla-Milsei were investigated. Strawberry plants were grown in a farm close to road Fernão Dias, South of Minas Gerais. Harvest took place in the morning of August 13, 2006. After harvest, fruits were placed under refrigeration, and brought to analyses. Fruits were evaluated for soluble solid contents, titratable acidity, and sensory attributes. Assays were carried out in three replications, in the Laboratory of Food and Sensory Analysis of the State University of Centro-Oeste (UNICENTRO), in Guarapuava, State of Paraná. Soluble solid contents, expressed in degrees Brix, were directly determined using a bench rephratometer Optech $^{\circledR}$, model RMT. The titratable acidity, expressed in percent of citric acid, was determined by the titrametric method (Instituto Adolfo Lutz, 1985).

Sensory analysis was carried out by a panel of 34 non-trained assessors, recruited out of UNICENTRO students, professors, and employees. Assessors evaluated the samples using sortingpreference tests and hedonic scale. According to his/her preferences, assessors were asked to sort the samples from the less preferred (score 1) to the most preferred (score 5), taking into account aroma and flavor. Each assessor evaluated five samples of each cultivar, previously randomized to avoid position bias, and presented in recipients with lids, coded with random three digitnumbers. Fruit external appearance was evaluated using a hedonic nine-point scale, anchored in the extremes "dislike very much" (score 1) and "like very much" (score 9). For this test, fruits of each cultivar were presented in polystyrene foam trays, covered with transparent PVC film. For evaluation, trays were displayed in a sampling bench, illuminate with white light.

Results were submitted to analysis of variance and means were compared using the Tukey test $(\mathrm{p}<0.05)$.

\section{RESULTS AND DISCUSSION}

Although cultivar Camp-dover had the highest score for fruit aroma, it was significantly different only from cultivar Dover, which presented the lowest score for this characteristic (Table 1). The pronounced aroma of cultivar Campdover fruits might be related to inheritable factors. Cultivar Campdover is an off-spring of the cross between cultivars Campinas and Dover, and it is known that cultivar Campinas possesses a high standard for fruit aroma (Passos \& Camargo, 1993).

Regarding fruit flavor, cultivar Camp-dover had again the highest score, significantly different from cultivars Dover, Camp-oso, and Tudla-Milsei, and similar to cultivar Oso Grande (Table 1). Fruit flavor is one of the most important characteristics in strawberry, but has a complex assessment, once it is related to several other attributes, especially the balance between sweet 
and acid constituents, fruit color, and ascorbic acid content (Flores-Cantillano et al., 2003).

According to Santos (1999), appearance is directly related to fruit color, external brightness, and shape. In strawberry, appearance is the quality attribute that has the strongest influence over price formation (Chitarra \& Chitarra, 2005). Cultivar Tudla-Milsei had the worst appearance according to assessors, significantly different from all other studied cultivars (Table 1). Among these, no significant differences were found. Cultivar Oso Grande, which typically produces large fruits, had the highest score for appearance. This behavior might have concurred to improve its appearance score.

Cultivars Camp-dover, Oso Grande, and Tudla-Milsei had the highest contents of soluble solids, significantly higher than cultivar Dover (Table 2). Regarding acidity, the highest values were found in fruits of cultivars TudlaMilsei, Oso Grande, and Dover, all significantly different from cultivar Camp-dover that did not differ from cultivar Camp-oso (Table 2). Cultivar Camp-dover had the highest soluble solids:titratable acidity ratio, significantly different from all other cultivars (Table 2).

A positive, significant, and reasonably high correlation (0.81) between aroma and flavor was observed, revealing that the chemical attributes that confer flavor are likely to be influencing also aroma. Positive and significant correlations were found also between soluble solid contents and both aroma (0.78) and flavor (0.98), showing that soluble solid contents influence aroma, but especially, flavor. Flavor corresponds to the perception of a blend involving sweetness, acidity, and astringency, in combination with aroma, due to the volatile compounds involved (Chitarra \& Chitarra, 2005). Negative, significant, and relatively high correlation (-0.77) was found between flavor and titratable acidity, pointing to the deterioration of flavor and increase in assessors refusal as the concentration of organic acids in fruit flesh raised. Nevertheless, the correlation between titratable acidity and aroma is non-

Tabela 1. Sensory panel scores for aroma, flavor, and appearance of strawberry fruits (notas da análise sensorial de aroma, sabor e aparência de frutos de morango). Guarapuava, UNICENTRO, 2006.

\begin{tabular}{lllc}
\hline Cultivar & Aroma & Flavor & Appearance \\
\hline Camp-dover & $3.70 \mathrm{a}^{*}$ & $3.82 \mathrm{a}$ & $7.00 \mathrm{a}$ \\
Dover & $2.40 \mathrm{~b}$ & $2.05 \mathrm{c}$ & $6.97 \mathrm{a}$ \\
Camp-oso & $3.15 \mathrm{ab}$ & $2.73 \mathrm{bc}$ & $6.95 \mathrm{a}$ \\
Oso Grande & $2.80 \mathrm{ab}$ & $3.52 \mathrm{ab}$ & $7.38 \mathrm{a}$ \\
Tudla-Milsei & $3.00 \mathrm{ab}$ & $2.85 \mathrm{bc}$ & $5.79 \mathrm{~b}$ \\
\hline
\end{tabular}

*Means followed by the same letter in the column, did not differ from each other, Tukey's test, $\mathrm{p}<0.05$ (médias seguidas da mesma letra nas colunas não diferem estatisticamente entre si, teste de Tukey, $\mathrm{p}<0,05)$.

Table 2. Soluble solid contents, titratable acidity, ratio soluble solids/titratable acidity, and correlation between sensory attributes and (1) soluble solids and (2) titratable acidity in strawberry fruits (teor de sólidos solúveis, acidez titulável, relação sólidos solúveis/acidez titulável e correlação entre atributos sensoriais e (1) teores de sólidos solúveis e (2) acidez titulável em frutos de morango). Guarapuava, UNICENTRO, 2006.

\begin{tabular}{|c|c|c|c|}
\hline Cultivar & $\begin{array}{c}\text { Soluble Solids (SS) } \\
{ }^{\circ B} \text { Brix }\end{array}$ & $\begin{array}{c}\text { Titratable Acidity } \\
\text { (TA) }\end{array}$ & SS/TA \\
\hline Camp-dover & $8.10 a^{*}$ & $0.60 \mathrm{~b}$ & $13,50 \mathrm{~A}$ \\
\hline Dover & $7.20 \mathrm{~b}$ & $0.80 \mathrm{a}$ & $9,00 \mathrm{c}$ \\
\hline Camp-oso & $7.40 a b$ & $0.62 a b$ & $11,90 \mathrm{bc}$ \\
\hline Oso Grande & $7.80 \mathrm{a}$ & $0.65 a$ & $12,00 \mathrm{ab}$ \\
\hline Tudla-Milsei & $7.60 \mathrm{a}$ & $0.88 a$ & $8,60 \mathrm{c}$ \\
\hline \multicolumn{4}{|c|}{ Correlations } \\
\hline Aroma x Flavor & Aroma $\times$ SS & Flavor $\times$ SS & Flavor $\times$ TA \\
\hline $0.81^{* *}$ & $0.78^{* *}$ & $0.98^{* *}$ & $-0.77^{* *}$ \\
\hline
\end{tabular}

* Means followed by the same letter in the column, did not differ from each other, Tukey's test, $\mathrm{p}<0.05$ (médias seguidas da mesma letra nas colunas não diferem estatisticamente entre si, teste de Tukey, $\mathrm{p}<0,05$ ); $* *$ Significant, test $\mathrm{t}, \mathrm{p}<0.05$ (significativo, teste $\mathrm{t}, \mathrm{p}<0,05$ ).

significant, although negative $(-0,60)$, which indicates that the presence of citric and malic acids did not alter fruit aroma to the point of significantly influence assessors preference (Table 1).

It is general sense that fruit flavor is directly related to the balance between soluble solids and acids. It is possible to infer based on our results that fruits from cultivars Camp-dover and Oso Grande, which had the best sugar:acid ratio, presented an acceptability pattern by assessors relatively higher than fruits from the other tested cultivars for aroma, appearance, and flavor.

Fruits from cultivars Camp-dover and Oso Grande, for their advantageous sensory attributes and high sugar:acid ratios, had the best acceptability. Therefore, the two cultivars are promising options for strawberry growing, and their good scores in attributes important for fresh consumption are likely to favor commercialization.

\section{REFERENCES}

CHITARRA MIF; CHITARRA AB. 2005. Póscolheita de frutos e hortaliças: fisiologia e manuseio. Lavras: FAEPE. 785 p.

FERREIRA VLP. 1999. Análise sensorial: testes discriminativos e afetivos. São Paulo: PROFÍQUA. $109 \mathrm{p}$.

FLORES-CANTILLANO F; BENDER RJ; LUCHSINGER L. 2003. Fisiologia e manejo pós-colheita. In: FLORES-CANTILLANO, F. Morango: pós-colheita. Brasília: EMBRAPA. p: $14-24$.

INSTITUTO ADOLFO LUTZ. 1985. Normas analíticas do Instituto Adolfo Lutz: métodos químicos e físicos para análises de alimentos. São Paulo. 371p.

LIMA LCO. 1999. Qualidade, colheita e manuseio pós-colheita de frutos de morangueiro. Informe Agropecuário 198: 80-83.

PASSOS FA; CAMARGO LS. Morango. In: FURLANI AMC; VIEGAS GP. 1993. O melhoramento de plantas no Instituto Agronômico. Campinas: Instituto Agronômico. p. 411-432. 
REICHERT LJ; MADAIL JCM. 2003 Aspectos sócio-econômicos. In: SANTOS AM; MEDEIROS AR. Morango: produção. Brasília: EMBRAPA. p. 12-15.
RONQUE ERV. 1998. Cultura do morangueiro: revisão e prática. Curitiba: EMATER-PR. 206p. SANTOS AM. 1999. Melhoramento genético do morangueiro. Informe Agropecuário 198: 24-29.
VEIGA JUNIOR WG. 2005. O morango e sua evolução comercial. In: CARVALHO SP (Coord.). Boletim do morango: cultivo convencional, segurança alimentar, cultivo orgânico. Belo Horizonte: CeasaMinas. 160p. 